\title{
Efektivitas antimikroba terhadap Pasteurella multocida dan Mannheimia haemolityca dari sapi yang diduga menderita bovine respiratory disease kompleks
}

\author{
Maria Luisa MNB Klobongona ${ }^{1}$, Usamah Afiff ${ }^{2}$, , Dordia Anindita Rotinsulu ${ }^{2}$ \\ ${ }^{1}$ Program Pendidikan Profesi Dokter Hewan, Fakultas Kedokteran Hewan, Institut Pertanian Bogor \\ ${ }^{2}$ Divisi Mikrobiologi Medik, Departemen Ilmu Penyakit Hewan dan Kesehatan Masyarakat Veteriner, \\ Fakultas Kedokteran Hewan, Institut Pertanian Bogor
}

\begin{abstract}
ABSTRAK: Penelitian ini bertujuan untuk mempelajari efektivitas beberapa jenis antibiotik terhadap Pasteurella multocida dan Mannheimia haemolityca dari sapi yang diduga menderita Bovine Rsepiratory Disease complex (BRD complex). Isolat diperoleh dari paru-paru sapi. Identifikasi bakteri menunjukkan adanya bakteri yang umum terlibat pada kasus $B R D$ complex seperti $P$. multocidadan $M$. haemolityca. Uji sensitivitas antimikroba dilakukan terhadap tujuh antibiotik (bacitracin, vancomicin, oxytetracycline, enrofloxacin, gentamicin, ampicillin, dan erythromycin) menggunakan metode Kirby-Bauer dengan mengukur diameter zona hambat. Interpretasi standar yang digunakan didasarkan pada Clinical Laboratory Standards Institute (CLSI). Hasil penelitian menunjukkan bahwa isolat P. multocida sensitif terhadap enrofloxacin, oxytetracycline, gentamicin, dan ampisilin; resisten terhadap bacitracin dan vankomisin; ke eritromisin. Sedangkan isolat M. haemolityca sensitif terhadap enrofloxacin dan gentamicin; resisten terhadap bacitracin, vankomisin, oksitosin ampisilin, dan eritromisin.
\end{abstract}

Kata kunci:

antibiotik, BRD kompleks, P. Multocida, M. Haemolityca.

\begin{abstract}
- PENDAHULUAN
Bovine respiratory disease (BRD) kompleks merupakan suatu penyakit saluran pernapasan pada sapi yang menimbulkan kerugian ekonomi yang besar. Menurut Griffin et al. (2010), Amerika Serikat mengalami kerugian industri peternakan akibat BRD kompleks mencapai 1 milyar dolar per tahun. Kasus BRD kompleks belum banyak dilaporkan di Indonesia dibandingkan dengan penyakit ngorok atau septicaemia epizootica (SE).
\end{abstract}

Mannheimia haemolytica, Pasteurella multocida, merupakan sebagian bakteri yang sering terlibat pada kasus BRD kompleks (Chmiel dan Grooms 2012). Saat ini banyak dilaporkan menurunnya efikasi pengobatan dari beberapa antibiotika yang umum dipakai untuk menangani kasus BRD kompleks. Hal ini disebabkan telah terjadi resistensi bakteri terhadap antibiotik sehingga efek terapi yang diinginkan tidak tercapai (Kuswandi 2011).

Resistensi terhadap antibiotik mengancam kesehatan dan kesejahteraan ternak, meningkatkan penggunaan antibiotika (Antimicrobial use/AMU) dan biaya produksi serta berpotensi dalam penyebaran gen resisten kepada bakteri lain di sapi dan juga lingkungan (Holman et al. 2015).

\section{- MATERI DAN METODE}

Bahan: Organ paru-paru sapi yang diduga terkena BRD komplek, isolat Pasteurella multocida dan Mannheimia haemolytica, antibiotik disk (basitrasin $10 \mathrm{IU}$, vankomisin $30 \mu \mathrm{g}$, oksitetrasiklin $30 \mu \mathrm{g}$, enrofloxasin $5 \mu \mathrm{g}$, gentamisin $10 \mu \mathrm{g}$, ampisilin $10 \mu \mathrm{g}$, dan eritromisin $15 \mu \mathrm{g}$ ), media isolasi dan identifikasi bakteri. Isolasi dan Identifikasi Bakteri: Isolasi dan identifikasi bakteri mengacu pada Jang et al. (1976), dan SMIs (2015). Pengujian Sensitivitas Antimikroba: Pengujian antibiotik dilakukan dengan metode agar difusi menurut Kirby-Bauer. Analisis Data: Data yang diperoleh berupa hasil identifikasi bakteri dan hasil pengukuran diameter zona hambat yang terbentuk. Selanjutnya data tersebut dianalisis secara deskriptif dengan mengacu pada Clinical Laboratory Standards Institute (CLSI 2008).

\section{- HASIL DAN PEMBAHASAN}

\section{Identifikasi Bakteri pada Sampel Paru-paru Sapi}

Pemeriksaan sampel paru-paru sapi yang diduga menderita BRD kompleks diperoleh tiga bakteri berbeda meliputi Pasteurella multocida,dan Mannheimia haemolytica. Data hasil pengukuran diameter zona hambat yang terbentuk pada pengujian sensitivitas antimikroba dari masing-masing antibiotik terhadap isolat $P$. multocida dan $M$. haemolytica disajikan pada Tabel 1.

Diterima: 23-03-2019 | Direvisi: 24-04-2019 | Disetujui: 15-05-2019

() 2019 CC-BY-SA. Ini adalah artikel Open Access yang didistribusikan berdasarkan ketentuan dari Creative Commons Attribution ShareAlike 4.0 International License (https://creativecommons.org/licenses/by-sa/4.0/). 
Tabel 1 Hasil uji sensitifitas isolat Pasteurella multocida dan Mannheimia haemolityca terhadap antibiotik.

\begin{tabular}{|c|c|c|c|c|}
\hline Antibiotik & Kons & Golongan & $\begin{array}{c}\text { Zona } \\
\text { Hambat } \\
(\mathrm{mm})\end{array}$ & Interpretasi \\
\hline \multicolumn{5}{|c|}{ Pasteurella multocida } \\
\hline B & $10 \mathrm{IU}$ & Polipeptida & 15.8 & $\mathrm{R}$ \\
\hline VA & $30 \mu \mathrm{g}$ & Glikopeptida & 9.7 & $\mathrm{R}$ \\
\hline OT & $30 \mu \mathrm{g}$ & Tetrasiklin & 35.7 & $\mathrm{~S}$ \\
\hline ENR & $5 \mu \mathrm{g}$ & Fluoroquinolon & 42 & $\mathrm{~S}$ \\
\hline $\mathrm{CN}$ & $10 \mu \mathrm{g}$ & Aminoglikosida & 27.3 & $\mathrm{~S}$ \\
\hline AMP & $10 \mu \mathrm{g}$ & Penisilin & 41 & S \\
\hline $\mathrm{E}$ & $15 \mu \mathrm{g}$ & Makrolida & 25.7 & I \\
\hline \multicolumn{5}{|c|}{ Mannheimia haemolityca } \\
\hline B & $10 \mathrm{IU}$ & Polipeptida & 7.9 & $\mathrm{R}$ \\
\hline VA & $30 \mu \mathrm{g}$ & Glikopeptida & 11.7 & $\mathrm{R}$ \\
\hline OT & $30 \mu \mathrm{g}$ & Tetrasiklin & 23.7 & $\mathrm{R}$ \\
\hline ENR & $5 \mu \mathrm{g}$ & Fluoroquinolon & 28.5 & S \\
\hline $\mathrm{CN}$ & $10 \mu \mathrm{g}$ & Aminoglikosida & 18 & $\mathrm{~S}$ \\
\hline AMP & $10 \mu \mathrm{g}$ & Penisilin & 6.7 & $\mathrm{R}$ \\
\hline E & $15 \mu \mathrm{g}$ & Makrolida & 13.7 & $\mathrm{R}$ \\
\hline
\end{tabular}

Keterangan: $\mathrm{B}=$ Basitrasin, $\mathrm{VA}=$ Vankomisin, $\mathrm{OT}=$ Oksitetrasiklin, $\mathrm{ENR}=$ Enrofloxasin, $\mathrm{CN}=$ Gentamisin, $\mathrm{AMP}=$ Ampisilin, $\mathrm{E}=$ Eritromisin, $\mathrm{R}=$ Resisten; $\mathrm{S}=$ Sensitif, $\mathrm{I}=$ Intermediet

\section{Efektivitas Antimikroba terhadap Isolat Pasteurella multocida}

Hasil pengujian antibiotik pada Tabel 1 menunjukkan bahwa $P$. multocida sensitif terhadap oksitetrasiklin, enrofloxasin, gentamisin, dan ampisilin. Interpretasi intermediet pada uji sensitivitas isolat $P$. multocida ditunjukkan oleh eritromisin. Berdasarkan laporan Guler et al. (2013) $80 \%$ isolat $P$. multocida sedikitnya telah memberikan hasil intermediet terhadap antibiotik eritromisin.

Hasil uji sensitivitas pada Tabel 1 menunjukkan adanya resistensi $P$. multocida terhadap basitrasin dan vancomisin. Kumar et al. (2009) melaporkan $75 \%$ dari total 38 isolat $P$. Multocida resisten terhadap basitrasin. Wulandari et al. (2013) melaporkan bahwa P. multocida telah resisten terhadap vankomisin.

\section{Efektivitas Antimikroba terhadap Isolat Mannheimia haemolityca}

Tabel 1 menunjukkan bahwa isolat $M$. haemolityca sensitif terhadap enrofloxasin dan gentamisin. Penelitian Seker et al. (2009) menunjukkan bahwa $90 \%$ dari 40 isolat $M$. haemolityca sensitif terhadap enrofloxasin dan $95 \%$ menunjukkan sensitif terhadap gentamisin.

Isolat M. Haemolityca resisten terhadap basitrasin, vankomisin, oksitetrasiklin, ampisilin, dan eritromisin. Nedbalcova et al. (2014) melaporkan sejak tahun 2007 sampai 2011, M. haemolityca telah resisten terhadap ampisilin dengan presentase berkisar 9.1\%-25\%. Seker et al. (2009) melaporkan $72.5 \%$ dari 40 isolat M. haemolityca telah resisten terhadap oksitetrasiklin dan $82.5 \%$ dari 40 isolat $M$. haemolityca resisten terhadap eritromisin.
SIMPULAN

Isolat Pasteurella multocida sensitif terhadap oksitetrasiklin, enrofloxasin, gentamisin, dan ampisilin. Isolat $P$. multocida resisten terhadap basitrasin dan vankomisin, dan intermediet terhadap eritromisin. Isolat $M$. haemolityca sensitif terhadap enrofloxasin dan gentamisin, serta resisten terhadap basitrasin, vankomisin, ampisilin, oksitetrasiklin, dan eritromisin.

\section{- INFORMASI PENULIS}

\section{Penulis untuk Korespondensi}

*UA: uafiff60@gmail.com

Divisi Mikrobiologi Medik, Departemen Ilmu Penyakit Hewan dan Kesehatan Masyarakat Veteriner, Fakultas Kedokteran Hewan, Institut Pertanian Bogor. J1 Agatis Kampus IPB Dramaga Bogor 16680

\section{PUSTAKA ACUAN}

[CLSI] Clinical Laboratory Standards Institute. 2008 Performance Standards for Antimocrobial Disk and Dilution Suseptibility Test for Bacterial Isolated from Animal. West Valley (US): Clinical and Laboratory Standards Institute.

[SMIs] UK Standards for Microbiology Investigation. 2015 Identification of Pasteurella spesies and morphologically similar organism. Public Health England. 3:1-28.

Chmiel RU, Grooms DL. 2012. Prevention and control of bovine respiratory disease. J Livestock Sci. 3:27-36.

Griffin D, Chengappa MM, Kuszak J, McVey DS. 2010. Bacterial pathogens of the bovine respiratory disease complex. Vet Clin Food Anim. 26:381-394.

Guler L, Gundus K, Sarisahin AS. 2013. Capsular typing and antimicrobial susceptibility of Pasteurella multocida isolated from different hosts. Kafkas Univ Vet Fak Derg. 19(5):843849 .

Holman DB, McAllister TA, Topp E, Wright A-DG, Alexander TW. 2015. The nasopharyngeal microbiota of feedlot cattle that develop bovine respiratory disease. Vet Microbiol, 180:90-95.

Jang SS, Biberstein EL, Hirsh DC. 1976. A Manual of Veterinary Clinical Bacteriology and Mycology. Davis (US): Univ California Pr.

Kumar P, Singh VP, Agrawal RK, Singh S. 2009. Identification of Pasteurella multocida isolates of ruminant origin using polymerase chain reaction and their antibiogram study. Trop Anim Health Prod. 41:573-578.

Kuswandi M. 2011. Strategi Mengatasi Bakteri yang Resisten terhadap Antibiotika. Di dalam: Pidato Pengukuhan Jabatan Guru Besar pada Fakultas Farmasi Universitas Gajah Mada. Yogyakarta (ID). Pp:10-12.

Nedbalcova K, Nechvatalova, Pokludova L, Bures J, Kucerova Z, Koutecka L, Hera A. 2014. Resistance to selected betalactam antibiotics. J Vet Mic. 6504:1-9.

Seker E, Kuyucuoglu Y, Konak S. 2009. Bacterial examination in the nasal cavity of apparently healthy and unhealthy holstein cattle. J Ani Vet Adv. 8(11):2355-2359.

Wulandari E, Jamin F, Abrar M. 2013. Kepekaan Pasteurella multocida yang diisolasi dari sapi yang berasal dari kabupaten Aceh Barat terhadap beberapa antibiotik. J Medika Veterinaria. 7(2):95-97. 